Сочинська-Сибірцева I. М., к.е.н., доцент

Центральноукраӥнський начіональний технічний університет м. Кропивницький, Україна DOI: https://doi.org/10.30525/978-9934-26-064-3-20

\title{
СИСТЕМА УПРАВЛІННЯ ЗНАННЯМИ НR-МЕНЕДЖЕРІВ У КОНТЕКСТІ КОМПЕТЕНТНІСНОГО ПІДХОДУ
}

Економічні реалії в Україні та світі демонструють, що успішно конкурувати за допомогою товарів і послуг практично неможливо: більшість 3 них легко копіюються $\mathrm{i}$ швидко втрачають цінність. Унікальним залишається лише людський капітал і здатність організації його постійно збагачувати. Такий стан речей формує нові виклики для HR-менеджерів. У теперішні часи роль таких нематеріальних ресурсів як професійні та персональні якості HR-менеджерів, особиста репутація і талант набувають першочергового значення. 
Один із найпоширеніших поглядів на цю проблему грунтується на застосуванні інноваційних технологій у вищій освіті, що обумовлені цілою низкою перетворень, серед яких: розробка та введення в дію нового покоління стандартів побудованих на компетентнісному підході, переосмислення ролі викладача та статусу студента. Відповідно виникає необхідність модернізації освітніх процесів та підвищення вимог щодо професійних якостей науково-педагогічних кадрів та результативності навчання. Це зумовлює необхідність застосування інноваційних технологій підготовки HR-менеджерів.

Міністерством освіти і науки України затверджено 04.03.2020 p. Стандарт вищої освіти України: другий (магістерський) рівень, галузь знань 05 «Соціальні та поведінкові науки», спеціальність 051 «Економіка» [1]. Стандарт вищої освіти містить компетентності, що визначають специфіку підготовки магістрів зі спеціальності 051 «Економіка» та результати навчання, які виражають що саме здобувач повинен знати, розуміти та бути здатним виконувати після успішного завершення освітньої програми. Вони узгоджені між собою та відповідають дескрипторам Національної рамки кваліфікацій (НРК). Заклад вищої освіти самостійно визначає перелік дисциплін, практик та інших видів навчальної діяльності, необхідний для набуття означених Стандартом компетентностей. Наведений в Стандарті перелік компетентностей і результатів навчання не є вичерпним. Заклади вищої освіти при формуванні профілю освітніх програм можуть вказувати додаткові компетентності і результати навчання.

Згідно стандарту здобувачі спеціальності повинні оволодіти трьома видами компетентностей - інтегральними, загальними $\mathrm{i}$ спеціальними (фаховими, предметними) та досягнути запрограмованих результатів навчання на належному рівні. У загальному розумінні сутність компетентнісного підходу наведена на рисунку 1.

Компетентність ми розглядаємо як володіння відповідною компетенцією, тобто - це спроможність кваліфіковано здійснювати діяльність; специфічна здатність людини використовувати i 
поєднувати набір знань, умінь, предметних навичок, способів мислення на рівні встановлених вимог (стандартів), здатність відповідально виконувати обов'язки і досягати запланованих результатів, знаходити вирішення у нестандартних ситуаціях.

Однією із інноваційних технологій формування та розвитку компетентностей HR-менеджера $\epsilon$ технологія освітнього менторства. Ї̈̈ сутність полягає у передаванні знань і умінь від більш досвідченої і компетентної людини менш досвідченій, шляхом співбесіди, консультації, поради чи методом ускладнюючих завдань.

Завдяки цій технології у здобувача формуються i розвиваються такі компетентності, як комунікативні (пов'язані 3 процесом спілкування), аналітичні (здатність креативного вирішення поставлених завдань), діагностичні (збір та обробка інформації). Технологія менторства цінна тим, що робить акцент не лише на професійному розвитку, але й сприяє психологічносоціальному розвитку особистості. Ментор забезпечує здобувача навчальними ресурсами, підтримкою, інструкціями, інформацією та зворотним зв'язком, порадами щодо прийняття рішень, ділитися власним досвідом і здобутками.

Отже, менторство як освітня технологія формування та удосконалення компетентностей здобувачів дозволяє отримати:

- корисну інформацію під час спілкування з ментором;

- практичну пораду i допомогу у процесі прийняття важливих професійних рішень;

- можливості обміну навчальними матеріалами чи ресурсами;

- набути необхідних навичок та вмінь в професійній діяльності.

Ефективність використання технології менторства у сфері вищої освіти в цілому i, зокрема, в процесі підготовки HR-менеджерів $є$ відчутно високою, дозволяє зробити освітній процес більш цікавим і сучасним, створює новий рівень взаємодії між здобувачем i викладачем, який найбільш наближений до реалій практичної професійної діяльності, стимулює здобувача до 


\section{самостійної роботи та дозволяє більш повно розкрити потенціал особистості.}

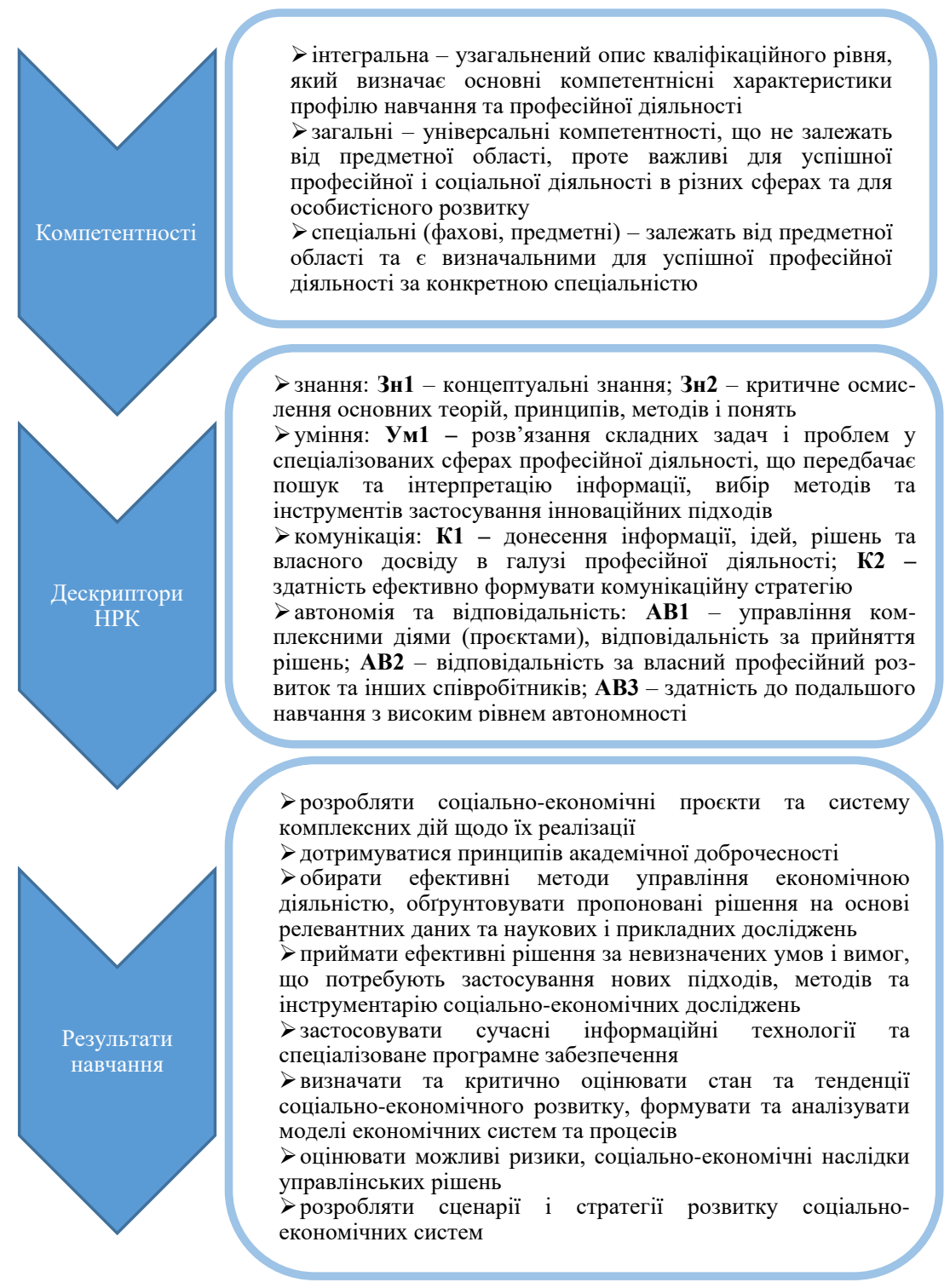

Рис. 1. Складові елементи компетентнісного підходу 
Технологія освітнього менторства також сприяє впровадженню моделі HR-компетенцій, яку запропонувала організацією The Society for Human Resource Management (SHRM) [2]. Організація об'єднує понад 300 тис. HR-професіоналів в 160 країнах. Модель HR-компетенцій SHRM вважається найбільш ефективною та визнаною в світовому бізнес-співтоваристві і складається із восьми поведінкових компетенцій, а саме: комунікації, управління відносинами, етичні норми i практики, бізнес-середовище, критичне мислення, консалтинг, лідерство i навігація в бізнесі, глобальна та культурна ефективність.

Визначальною характеристикою HR-менеджера в умовах форс-мажору має стати розвинена емпатія. Ця якість полягає в умінні поставити себе на місце іншої людини і побачити ситуацію з ії точки зору [3].

Розвинена емпатія проявляється в умінні:

- слухати і чути співробітників;

- виявляти потреби та корегувати персональну мотивацію;

- своєчасно визнавати досягнення співробітника (як у контексті роботи, так і на рівні особистості).

Таким чином, в руслі інноваційних змін необхідна активізація використання сучасних освітніх технологій в контексті компетентнісного підходу, які відповідають динамічним процесам бізнес-середовища, а також сприяють підвищенню конкурентоспроможності HR-менеджерів.

\section{Література:}

1. Стандарт вищої освіти України. URL: https://mon.gov.ua/storage/ app/media/vishcha-osvita/zatverdzeni\%20standarty/2020/03/051-ekonomika-M.pdf

2. Менеджер $з$ персоналу. URL: https://business.ua/strategii/item/2018-vidhrmenedzhera-do-hrlidera-novoi-heneratsii

3. Главный критерий подбора сотрудников в 2020 году - эмпатия. URL: https://www.hr-director.ru/news/68011-qqn-20-m01-glavnyy-kriteriy-podbora-sotrudnikov-v-2020-godu-empatiya 